\title{
Does Foreign Institutional Equity Participation Instigate Sustainable Corporate Investment Efficiency? Evidence from Emerging Economies
}

\author{
Sabahat Riaz (D), Mohamed Hisham Hanifa * (D) and Fauzi Zainir \\ Department of Finance and Banking, Graduate School of Business, University of Malaya, \\ Persekutuan Kuala Lumpur 50603, Malaysia; cva170034@siswa.um.edu.my (S.R.); zfauzi@um.edu.my (F.Z.) \\ * Correspondence: mhisham@um.edu.my; Tel.: +60-122-203-515
}

check for updates

Citation: Riaz, S.; Hanifa, M.H.; Zainir, F. Does Foreign Institutional Equity Participation Instigate Sustainable Corporate Investment Efficiency? Evidence from Emerging Economies. Sustainability 2021, 13, 4190. https://doi.org/10.3390/ su13084190

Academic Editors: Pompeo Della Posta, Enrico Marelli and Marcello Signorelli

Received: 17 March 2021

Accepted: 6 April 2021

Published: 9 April 2021

Publisher's Note: MDPI stays neutral with regard to jurisdictional claims in published maps and institutional affiliations.

Copyright: (c) 2021 by the authors. Licensee MDPI, Basel, Switzerland. This article is an open access article distributed under the terms and conditions of the Creative Commons Attribution (CC BY) license (https:// creativecommons.org/licenses/by/ $4.0 /)$.

\begin{abstract}
This study examines the impact of overall foreign institutional equity participation and its two types-foreign institutional pressure-resistant and pressure-sensitive- on firm sustainable investment efficiency for non-financial listed domestic firms of three emerging economies over the period of 2009-2018, using an unbalanced panel of 733 firms with 4468 firm-year observations. It also investigates the impact of varying levels of foreign equity participation on investment efficiency. We used the regression estimation technique with robust standard errors clustered at the firm level. We also used the second-stage instrumental variable (IV) method to control potential endogeneity. Empirical findings reveal that overall foreign institutional equity participation and foreign institutional pressure-resistant ownership have a positive and significant impact on corporate investment efficiency, whereas foreign institutional pressure-sensitive ownership has a positive but insignificant impact. When we divided the overall institutional foreign equity ownership and its two types into five levels, we found a positive and significant impact of overall foreign institutional ownership at all levels. The foreign institutional pressure-resistant ownership has a positive and significant impact on investment efficiency when it is greater than $10 \%$. However, we found a weak relationship of foreign institutional pressure-sensitive equity ownership with investment efficiency at all varying levels of investments. These results are robust when we controlled for endogeneity. Our results have implications for policymakers, regulators, academicians, and potential foreign equity participants. These results can be generalized to those emerging economies that have the potentials for attracting foreign equity inflows.
\end{abstract}

Keywords: foreign equity; pressure-resistant; pressure-sensitive; sustainable investment efficiency; emerging economies

\section{Introduction}

Corporate investment decisions are crucial for managers ensuring shareholders' wealth maximization and enhanced firm value. Efficient resource allocation among valuemaximizing projects ensures minimal agency costs and the rationale for managers' high perks and benefits [1,2]. The outcome of firms' investment decisions influences the firms' future earning potential, cash-flow sensitivity, long-term growth, corporate value, and sustainability [3-5]. Relaxing the assumption of a frictionless capital market, existing empirical literature elucidates deviations from optimal capital investment, either in the form of over-investment or under-investment. Theoretically, sub-optimal investment primarily tends to fluctuate due to two underlying notions comprising agency issues [6] and information asymmetries [7].

Agency theory postulates that investment efficiency fluctuates due to investors' and managers' conflicting risk behaviors, usually termed as moral hazard where managers over-utilize funds (free cash flows) in low value (even negative net present value) projects for the sake of their perks and benefits $[7,8]$. It leads to investment inefficiency, resulting 
from the over-investment of available free cash flows [9]. The information asymmetry suggests that managers, facing financial constraints, use their discretionary powers for capital rationing by avoiding growth opportunities, leading to investment inefficiency, resulting from under-investment $[10,11]$.

Examining corporate investment efficiency has remained crucial because of its diverse determinants in accounting and finance disciplines. Prior studies portray corporate investment efficiency as a function of risk and return under available growth opportunities and restricted financial arrangements [12,13], quality and transparency of financial reporting [14-16], and financial development [4,10,17]. Some recent empirical studies examine the complex ownership structures with varying monitoring levels and reduced managerial entrenchment capabilities, which affect corporate investment strategies. The impact of ownership structure on firm investment efficiency has been elaborated in terms of either total institutional equity participation (e.g., see $[1,3,16]$ ) or total foreign institutional equity participation (e.g., see [13,17-19]). Moreover, very few studies $[18,20]$ segregate institutional investors into two types of pressure-resistant and pressure-sensitive foreign institutional investors. Institutional pressure-resistant investors (e.g., mutual funds, investment brokers and advisors, and pension funds) are "active shareholders" who mostly focus on monitoring firms' managerial actions by raising their voice against contentious matters, with fewer business ties and regulatory restrictions [21,22], whereas institutional pressure-sensitive investors (e.g., banks, insurance companies, trusts, and other institutions) are "passive shareholders" who tend to have close business ties and absorb pressure from their portfolio firms' management without articulating their sentiments [21,23,24].

It is evident from the prevailing literature that foreign equity participation, resulting from financial openness and integration in domestic firms, has influenced corporate investment strategies, accountability, transparency, and survival profiles $[3,20,25,26]$. The presence of foreign institutional ownership has dramatically curtailed corporate philosophy from the traditional capitalism model (concentrated ownership with long-term relations with stakeholders) to the shareholders' model of scattered and diverted nature of ownership $[27,28]$. Consequently, domestic firms have witnessed a substantial increase in foreign institutional shareholdings due to the liberalization of the equity investment climate. Accordingly, it has raised concerns whether the foreign shareholders' presence enhances domestic firms' investment efficiency or if investment efficiency attracts foreign shareholders. These studies, in other words, lack the causal effect of foreign institutional ownership endogeneity that needs to be addressed through omitted variables of the firms' fixed effects that control unobserved firm heterogeneity [28]. Besides, it is also essential to address the impact of segregated foreign equity participation (pressure-resistant and pressure-sensitive) on domestic firm investment efficiency because of their varying business ties, monitoring capabilities, and influential role in management, governance, and corporate strategy of a domestic firm.

The aim of this study is to investigate the impact of overall foreign institutional equity participation on corporate investment efficiency. We examined the impact of foreign institutional equity participation by segregating it into its two types of pressure-resistant and pressure-sensitive investors. We also examined the impact of varying levels of foreign institutional equity participation and its types on investment efficiency among three countries Indonesia, Malaysia and Singapore, selected from the Association of Southeast Asian Nations (ASEAN). Hereafter we refer to these three countries as ASEAN-3. Examining emerging ASEAN-3 countries is indispensable for the following reasons. First, these neighboring countries have remained attractive for foreign inflows due to foreign investors' quick operational setups at lower transaction investment costs, free economic zones, corporate facilitation assurance, and induced agglomeration and cluster benefits [29]. Second, the liberalization of investment policies, ease of entry requirements, simplified administrative procedures, and less stringent regulatory requirements to attract foreign investors for investing in domestic firms have promoted foreign portfolio equity investments. Third, the World Bank's economic indicators from 2009 to 2018 indicate, despite the 
2007-2008 financial crisis, an upsurge in foreign equity portfolio investments in ASEAN countries, including Indonesia, Malaysia, and Singapore.

Empirical findings reveal that overall foreign institutional ownership and foreign pressure-resistant institutional ownership have a positive and significant impact on corporate investment efficiency, whereas foreign institutional pressure-sensitive ownership has a positive but insignificant impact. The findings also reveal that varying levels of overall institutional foreign equity ownership and its two types have a different effect on corporate investment efficiency.

Our study contributes to the existing literature on corporate investment efficiency by segregating foreign institutional ownership into pressure-resistant and pressure-sensitive foreign institutional investors. It highlights the extent and direction of both types of foreign institutional equity participation on sustainable corporate investment efficiency. It also depicts the impact of varying levels of foreign institutional ownership and its types in determining optimal investment efficiency levels in domestic listed firms of emerging economies.

The rest of the paper has been organized as follows. Section 2 elaborates the relevant literature and describes the hypothesis of the study. Section 3 describes the research methodology comprising research design, data description, and econometric modeling. Section 4 highlights the empirical results of the study. Section 5 discusses the findings, along with the generalizability of the findings and suggestions for future research. Section 6 concludes the study.

\section{Literature Review and Hypothesis}

\subsection{Theoretical Background}

Prior studies suggest agency issues and information asymmetry are the major causes of corporate investment inefficiency $[9,17,30]$. Agency issues [8,31,32] stem from public corporations' underlying characteristics of the separation of ownership and control. Agency issues reflect conflicting risk behaviors of principals (shareholders) and agents (managers). Managers tend to over-utilize funds (free cash flows) in low-value projects, due to their wealth maximization, short-termism [33], and overconfidence [34]. This tendency leads to sub-optimal investments. On the other hand, the asymmetric information theory [7] suggests that managers have more information about economic transactions than shareholders. They have discretionary powers for capital rationing by avoiding growth opportunities. To reduce unsystematic risk, the shareholders expect the managers to avail themselves of riskier investment opportunities, whereas managers, based on information asymmetry, usually opt for risk-averse behavior to protect their wealth, careers, and an extended stay in firms. This risk-averse behavior also leads to sub-optimal investments.

Within the context of foreign ownership, investment efficiency is evaluated based on investment sensitivity to cash flows, where foreign investment is presumed to result from a good financial position and corporate governance of the firm [35]. Optimal investment decisions determine firms' future cash flow, earnings stability, and sustainable growth; therefore, investment efficiency is influenced by ownership structure (domestic, foreigners, individuals, and institutional) on the premise of agency cost and information asymmetry $[1,36]$.

\subsection{Empirical Context}

Over the last two decades, institutional investors' effective monitoring roles have gained importance both in shareholders' and stakeholders' oriented governance systems [3]. Institutional investors are well-informed, hold an influential role in the management, and monitor effective utilization of resources at a low cost [21,37]. Institutional investors' presence eradicates the investor-manager conflicting interest anomaly and exerts performance pressure on management via voting rights (voice) or threats to quit firms [38]. Furthermore, institutional investors' presence as insiders promotes long-term investment, innovation, and human capital development because of the disciplinary effect of insiders [28]. 
Empirical evidence, however, reveals that all institutional investors do not possess the same corporate investment objectives [24]. Cao et al. [1] have examined the impact of overall institutional investors and their two types on investment efficiency. Their finds suggest that the investment objectives of pressure-resistant investors are different from pressure-sensitive institutional investors. Institutional pressure-resistant investors are "active shareholders" who primarily focus on monitoring firms' managerial actions by raising their voices against contentious matters, with fewer business ties and regulatory restrictions [21,22]. In comparison, institutional pressure-sensitive investors are "passive shareholders" who tend to have close business ties and absorb pressure from their portfolio firms' management without articulating their sentiments [21,23,24].

Chen et al. [2] highlight the role of different ownership types, particularly the unique role of foreign institutional ownership. Foreign investors have an extrusive monitoring role [21,39]. Foreign investors promote riskier investments because of their ability to reduce managerial entrenchment to promote investment efficiency. Empirical studies generalize that investment inefficiency arising from agency cost and information asymmetry is reduced in foreign institutional investors' presence via effective monitoring of firms' operational policies [40-42]. The presence of foreign institutional investors in domestic firms ensures better monitoring of strategic investment decisions and preferred riskier projects [28]. The literature also reveals that foreign equity participation reduces financial constraints, as financial intermediaries consider foreign investors' presence to be a symptom of low information asymmetry [35].

Foreign ownership brings effective monitoring, risk-taking propensity, and expert advisories for business decisions [43]. Foreign investors play an influential role from an independent position when controlling shareholders exercise exclusive controlling power to justify their self-serving behaviors in every aspect. Foreign investors restrict managers' opportunistic behaviors (i.e., an intention to extract private benefits) and support firm value to maximize shareholder benefits, which improves firm performance and investment efficiency [44]. It is believed that foreign equity participation boosts other investors' confidence on the premise that foreigners only invest in firms with good corporate governance, which in turn enhances investment efficiency and growth prospects [21].

Based on the above discussion, we argue that foreign institutional equity participation enhances domestic firms' investment efficiency because of effective monitoring, reduced managerial entrenchment, preferred riskier investments, and the exercising of a disciplinary insider role. Accordingly, the following is our first hypothesis.

Hypothesis 1. Overall, foreign institutional ownership enhances corporate investment efficiency in domestic firms.

Most of the studies have not segregated foreign ownership into its two broad types, pressure-resistant (independent) and pressure-sensitive (grey), which have varying impacts on capital investment decisions [24]. There are very few studies [21,24] that segregate foreign institutional investors into their two sub-types of pressure-resistant and pressure-sensitive foreign institutional investors. Ferreira and Matos [24] report a significant and positive impact of foreign institutional pressure-resistant investors' presence on firm performance, valuation, and capital expenditure planning because of their active participation, strong monitoring, and fewer business ties with corporate management. Aggarwal et al. [21] argue that foreign institutional pressure-resistant investors possess more corporate information and fewer regulatory restrictions. In comparison, foreign institutional pressure-sensitive investors are "passive shareholders" who tend to have close business ties and absorb pressure from their portfolio firms' management without articulating their sentiments $[21,23,24]$. Monitoring is usually considered more costly to pressure-sensitive investors, which ultimately is disadvantageous for them, as it may harm their close business ties. 
Accordingly, the proposed study divides the main hypothesis into two sub-hypotheses to test the extent and degree to which the above two segregations impact corporate investment efficiency. This study tested the following two sub-hypotheses.

Hypothesis 1a. Foreign institutional pressure-resistant ownership upsurges the corporate investment efficiency in domestic firms.

Hypothesis $\mathbf{1 b}$. Foreign institutional pressure-sensitive ownership has no significant impact on domestic firms' investment efficiency.

Some studies $[2,45]$ have also investigated the impact of varying degrees of foreign equity participation to measure the dominant level that enhances investment efficiency. Chen et al. [2] argue that varying degrees of foreign institutional owners lead to different investment behaviors and investment efficiency. Peck-Ling et al. [45] suggest varying levels of foreign ownership have different dominant impacts on firm performance. In light of the above arguments, we tested the impact of varying levels of overall foreign institutional equity participation and its two types on firm investment efficiency. The following is our second hypothesis.

Hypothesis 2. High levels of foreign institutional equity participation significantly impact corporate investment efficiency.

\section{Research Methodology}

\subsection{Research Design and Model}

This study is explanatory as it tested a priori hypotheses, that is, outcome predictions made before the measurement phase began, based upon quantitative data. Following the definition of investment inefficiency (the difference between actual and expected investment) by Biddle et al. [15], we used the investment expectation model proposed by Richardson [46], as shown in Equation (1). The fitted value of the investment expectation model is the expected investment. The value of residuals of this model depicts investment inefficiency.

$$
\begin{aligned}
\mathrm{INV}_{\mathrm{i}, \mathrm{t}}= & \beta_{0}+\beta_{1} \mathrm{INV}_{\mathrm{i}, \mathrm{t}-1}+\beta_{2} \mathrm{CF}_{\mathrm{i}, \mathrm{t}-1}+\beta_{3} \mathrm{SIZE}_{\mathrm{i}, \mathrm{t}-1}+\beta_{4} \mathrm{TQ}_{\mathrm{i}, \mathrm{t}-1}+\beta_{5} \mathrm{ROA}_{\mathrm{i}, \mathrm{t}-1}+\beta_{6} \mathrm{LEV}_{\mathrm{i}, \mathrm{t}-1}+\beta_{7} \mathrm{AGE}_{\mathrm{i}, \mathrm{t}} \\
& +\sum_{\mathrm{c}} \mathrm{CNT}+\sum_{\mathrm{i}} \mathrm{IND}+\sum_{\mathrm{t}} \mathrm{YEAR}+\varepsilon_{i, t}
\end{aligned}
$$

where subscripts i and $t$ denote firm and year, respectively. The dependent variable, INV, represents investment expenditure measured as the difference between capital expenditure and property, plant, and equipment, adjusted by depreciation and amortization, and divided by total assets. The definitions, measurements, and data sources of variables are presented in Table 1. The study also controlled for country, industry, and year-specific effects on capital investment expenditures.

Following Cao et al. [1] and Gomariz and Ballesta [16], the residuals $\varepsilon_{i, t}$ generated from Equation (1), representing investment inefficiency, were multiplied by -1 to generate the investment efficiency, that is, $-\varepsilon_{i, t}$. A higher value of $-\varepsilon_{i, t}$ indicates higher investment efficiency and vise versa. We use this value, representing a firm-specific proxy for investment efficiency, as dependent variable $\left(\mathrm{INV}_{-} \mathrm{EF}_{\mathrm{i}, \mathrm{t}}\right)$ in Equation (2) to test the stated hypotheses of this study.

$$
\begin{aligned}
& \mathrm{INV}_{-} \mathrm{EF}_{\mathrm{i}, \mathrm{t}}=\beta_{0}+\beta_{1} \mathrm{~F}_{-} I N S T_{i, t}+\beta_{2} \mathrm{FCF}_{\mathrm{i}, \mathrm{t}}+\beta_{3} \mathrm{~A}_{-} \mathrm{TAN}_{\mathrm{i}, \mathrm{t}}+\beta_{3} \mathrm{SLACK}_{\mathrm{i}, \mathrm{t}}+\beta_{5} \mathrm{ORC}_{\mathrm{i}, \mathrm{t}}+\beta_{6} \mathrm{DIV}_{\mathrm{i}, \mathrm{t}}+\beta_{7} \mathrm{~F}_{-} \mathrm{LEV}_{\mathrm{i}, \mathrm{t}}+\beta_{8} \mathrm{SIZE}_{\mathrm{i}, \mathrm{t}} \\
& +\sum_{\mathrm{f}} \text { FIRM }+\sum_{\mathrm{t}} \text { YEAR }+\varepsilon_{\mathrm{i}, \mathrm{t}}
\end{aligned}
$$

INV_EF is measured by multiplying the residual of Equation (1) with (-1). F_INST is the total foreign institutional equity participation in testing for H1. F_INST is replaced with FINST_PR for pressure-resistant and with FINST_PS for pressure-sensitive foreign 
institutional investors, testing for $\mathrm{H} 1 \mathrm{a}$ and $\mathrm{H} 1 \mathrm{~b}$, respectively. We expected the coefficient of $\beta_{1}$ to be positive and significant for the hypotheses H1, H1a. The rest of the control variables that may affect investment efficiency include free cash flows, assets tangibility, financial slack, other receivable claimants, dividend, firm size, firm, and year fixed effects used by previous studies. The availability of excess free cash flows (FCF) allows for expanding resources beyond the optimal level [46]. We included assets' tangibility because firms with more tangible assets capture more external finance at favorable terms and conditions [47]. Financial slack (SLACK) represents a buffer that firms use during uncertain timings to avail potential growth and innovative investment opportunities $[7,48]$. Other receivable claimants (ORC) control by proxy substantial stockholders' effect on investment efficiency [1]. We controlled dividends (DIV) because dividend-paying firms may forgo available investment opportunities to maintain their dividend policy. We also controlled conventional variables, like financial leverage and firm size, as suggested by various studies $[4,18,49]$.

The study included firm and year effects to control unobserved heterogeneity. We estimated our main model using robust standard errors clustered at the firm level to address the heteroskedasticity and autocorrelation concerns with the year and firm fixed effects. In addition, we used the second-stage instrumental variable estimation technique to address the potential endogeneity issue. We estimated the robustness using the generalized method of moments (GMM). The study also deployed the vector error correction (VEC) Granger causality test to evaluate the causality of explanatory and response variables. Table 1 contains the definitions and measurements of these variables.

Table 1. Variable definitions and measurements.

\begin{tabular}{|c|c|c|}
\hline Variable Name & Variable Notation & Measurement \\
\hline Corporate Investment & INV & $\begin{array}{c}\text { Capital expenditures plus research and } \\
\text { development expense, divided by lagged } \\
\text { total assets }\end{array}$ \\
\hline Cash Flow & $\mathrm{CF}$ & $\begin{array}{l}\text { Cash flow from operating activities, divided by } \\
\text { total assets }\end{array}$ \\
\hline TobinQ & TQ & $\begin{array}{l}\text { Market value of equity plus total liabilities, } \\
\text { divided by book value of assets, calculated as } \\
\text { (market value + total liabilities)/total assets. }\end{array}$ \\
\hline Return on Assets & ROA & Ratio of net profit after tax to total assets \\
\hline Firm Age & AGE & Number of years since listing on stock market \\
\hline Investment Efficiency & INV_EF & $\begin{array}{l}\text { Absolute residuals value obtained from the } \\
\text { Equation (1) regression and multiplied by }(-1)\end{array}$ \\
\hline Foreign Institutional Ownership & F_INST & Percentage of shares held by foreigner investors \\
\hline $\begin{array}{l}\text { Foreign Pressure-Resistant Institutional } \\
\text { Ownership }\end{array}$ & FINST_PR & $\begin{array}{l}\text { Percentage of shares held by foreigner } \\
\text { pressure-resistant investors }\end{array}$ \\
\hline $\begin{array}{l}\text { Foreign Pressure-Sensitive Institutional } \\
\text { Ownership }\end{array}$ & FINST_PS & $\begin{array}{l}\text { Percentage of shares held by foreigner } \\
\text { pressure-sensitive investors }\end{array}$ \\
\hline Free Cash Flow & FCF & $\begin{array}{l}\text { Difference of operating cash flow and capital } \\
\text { expenditure scaled by total assets }\end{array}$ \\
\hline Assets Tangibility & A_TAN & Net PPE scaled by lagged total assets \\
\hline Financial Slack & SLACK & Ratio of cash to property plant and equipment \\
\hline Other Receivables Claimant & ORC & Ratio of other receivables to total assets \\
\hline Dividend Paid by Firm & DIV & $\begin{array}{l}\text { An indicator variable with the value of } 1 \text { if a firm } \\
\text { pays dividends, zero otherwise }\end{array}$ \\
\hline Financial Leverage (a) & F_LEV & Ratio of total debt to book value of assets \\
\hline Firm Size & $\overline{\mathrm{SIZE}}$ & Natural logarithm of book value of assets \\
\hline Financial Leverage (b) & F_LEV & Ratio of total debt to lagged assets \\
\hline Loss Incurred by Firm & LOSS & $\begin{array}{c}\text { An indicator variable that takes a value of } 1 \text { if net } \\
\text { loss is incurred in a given year, and } \\
\text { zero otherwise }\end{array}$ \\
\hline Revenue & REV & Net sales revenue divided by lagged total assets \\
\hline
\end{tabular}




\subsection{Data Description}

The population comprised all listed domestic firms from the non-financial sector of selected ASEAN-3 countries (Indonesia, Malaysia, and Singapore) with foreign institutional investors presence. We excluded domestic firms from the financial sector because of different regulations. Firms with less than three years of having foreign institutional investors were excluded. Accordingly, the final sample comprised an unbalanced panel consisting of 733 firms in total and 4,468 firm-year observations. The data was collected from relevant stock exchanges, databases (Eikon DataStream and Bloomberg), and securities commissions from 2009 to 2018. Figure 1 justifies the rationale of data from 2009 to 2018 on the premise of an upsurge in net portfolio investments following the financial crisis. Net foreign equity portfolio inflows in Indonesia remained mostly positive and more consistent than the other two ASEAN countries. Singapore, however, performed well in attracting foreign inflows, as compared to Indonesia and Malaysia. Moreover, the data before 2009 contains missing values.

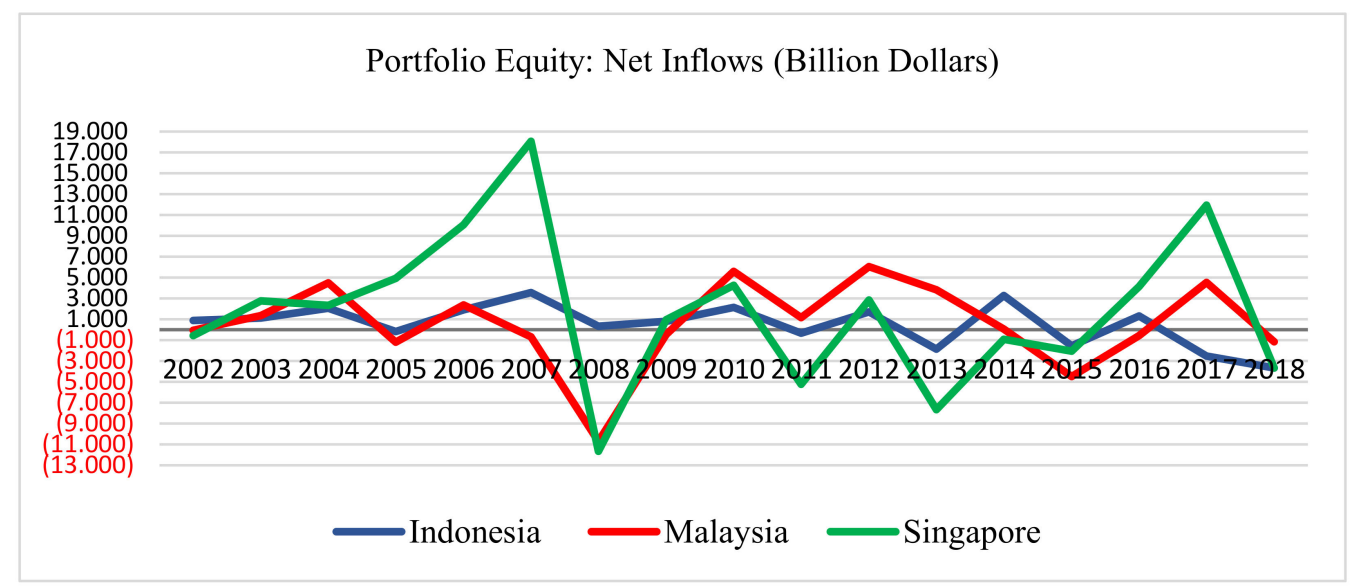

Figure 1. Source: World Bank Economic Indicator.

\section{Empirical Results}

\subsection{Descriptive Statistics}

Table 2 depicts the key statistics of the sample data comprising predictors and response variables. All variables have been Winsorized at the 1st and 99th percentile to resolve data abnormality issues, except the dummy variable (dividend). INV_EF has a mean value of 0.0000959 and a standard deviation of 0.156685 . It ranges from a minimum value of -0.37778 to a maximum of 0.41485 . The mean value of overall foreign institutional investors is $5.49 \%$, which tends to fluctuate from a very low percentage of $0.01 \%$ to a high percentage of $40.54 \%$, with a volatility of $7.71 \%$. The mean value of pressure-resistant foreign institutional investors is $4.07 \%$, ranging from a minimum of $0.01 \%$ to a maximum of $31.08 \%$. The mean value of pressure-sensitive foreign institutional investors is $5.59 \%$, ranging from a minimum of $0.008 \%$ to a maximum of $45.62 \%$. With a standard deviation of $5.22 \%$, foreign pressure-resistant institutional investors are inferred as more stable than foreign pressure-sensitive institutional investors, which have a high deviation of $9.64 \%$. The descriptive statistics for the rest of the control variables are to be interpreted similarly. 
Table 2. Descriptive statistics.

\begin{tabular}{cccccc}
\hline Variables & Obs & Mean & Std. Dev. & Min & Max \\
\hline INV_EF & 6408 & 0.0000959 & 0.156685 & -0.37778 & 0.41485 \\
F_INST & 5743 & 0.0549844 & 0.077149 & 0.0001 & 0.405474 \\
FINST_PR & 4538 & 0.0407418 & 0.052238 & 0.0001 & 0.31080 \\
FINST_PS & 2418 & 0.0559310 & 0.0964404 & 0.00008 & 0.456272 \\
FCF & 7556 & 0.0140367 & 0.1091604 & -0.3717271 & 0.3570234 \\
A_TAN & 7288 & 0.3618012 & 0.2605447 & 0.0029903 & 1.27241 \\
SLACK & 7453 & 1.150727 & 3.584122 & 0.0029227 & 27.69412 \\
ORC & 6626 & 0.0332029 & 0.0557522 & 0.0000858 & 0.3298002 \\
DIV & 8020 & 0.6649626 & 0.472033 & 0 & 1 \\
F_LEV & 7484 & 0.2183304 & 0.2052407 & 0 & 0.932771 \\
SIZE & 7576 & 5.414979 & 0.7188431 & 3.848565 & 7.314333 \\
\hline
\end{tabular}

\subsection{Correlation Analysis}

The Pearson correlation analysis in Table 3 reveals no serious multicollinearity issues for the main model's explanatory variables. The highest correlation of 0.4528 exists between financial leverage and firm size. Furthermore, the multicollinearity issue was cross-verified through the variance inflation factor (VIF), where the VIF for all explanatory variables is less than 4.50 .

Table 3. Pearson correlation matrix.

\begin{tabular}{|c|c|c|c|c|c|c|c|c|c|c|}
\hline Variables & F_INST & FINST_PR & FINST_PS & FCF & A_TAN & SLACK & ORC & DIV & F_LEV & SIZE \\
\hline F_INST & 1.0000 & & & & & & & & & \\
\hline FIN̄ST_PR & -0.0708 & 1.0000 & & & & & & & & \\
\hline FINST_PS & -0.0024 & 0.0897 & 1.0000 & & & & & & & \\
\hline FCF & 0.0088 & -0.0256 & 0.0181 & 1.0000 & & & & & & \\
\hline A_TAN & -0.0425 & 0.0487 & -0.0418 & -0.1233 & 1.0000 & & & & & \\
\hline SLACK & 0.0165 & -0.0519 & -0.0343 & -0.0718 & -0.2789 & 1.0000 & & & & \\
\hline ORC & -0.0297 & -0.0650 & 0.0622 & -0.1251 & -0.2610 & 0.1002 & 1.0000 & & & \\
\hline DIV & 0.0246 & 0.0064 & -0.0009 & 0.2426 & 0.0890 & -0.1283 & -0.2368 & 1.0000 & & \\
\hline F_LEV & -0.1117 & 0.1154 & -0.0425 & -0.3226 & 0.1738 & -0.0442 & 0.1015 & -0.0878 & 1.0000 & \\
\hline SIZE & -0.0172 & 0.1474 & 0.0401 & -0.0192 & 0.1898 & -0.1410 & -0.0375 & 0.1963 & 0.4528 & 1.0000 \\
\hline
\end{tabular}

\subsection{Inferential Statistics}

Table 4 reports the regression results for the investment expectation model of Richardson [46]. We used a dynamic model by taking the lag of all the explanatory variables, except age, to control unobserved factors and remove simultaneity issues, as suggested by Guariglia and Yang [9]. These results were then used to calculate the residuals of the fitted model. After multiplying with -1 , the estimated residuals were used as a dependent variable (INV_EF) for the main Model 2.

Table 4. Regression results of the investment expectation model.

\begin{tabular}{cccccccc}
\hline $\mathbf{I N V}_{\mathrm{i}, \mathrm{t}-\mathbf{1}}$ & $\mathbf{C F}_{\mathbf{i}, \mathbf{t}-\mathbf{1}}$ & $\mathbf{S I Z E}_{\mathbf{i}, \mathbf{t}-\mathbf{1}}$ & $\mathbf{T Q}_{\mathbf{i}, \mathbf{t}-\mathbf{1}}$ & $\mathbf{R O A}_{\mathbf{i}, \mathbf{t}-\mathbf{1}}$ & $\mathbf{L E V}_{\mathbf{i}, \mathbf{t}-\mathbf{1}}$ & AGE $_{\mathbf{t}}$ & Adj. R2 \\
\hline $0.4281^{* * *}$ & 0.0519 & $-0.0513^{* * *}$ & $0.0039^{* *}$ & $0.000704^{* *}$ & $-0.0043^{* * *}$ & -0.0072 & 0.2545 \\
$(38.22)$ & $(1.58)$ & $(-7.04)$ & $(2.19)$ & $(2.01)$ & $(-2.92)$ & $(-1.21)$ & \\
\hline
\end{tabular}

${ }^{* * *} p<0.001,{ }^{* *} p<0.05,{ }^{*} p<0.10$.

Table 5 reports the results of Model 2, comprising the relationship of overall foreign institutional, foreign pressure-resistant, and foreign pressure-sensitive institutional equity participants with investment efficiency. Column (1) indicates that F_INST is positive and has a significant relation with INV_EF at a $1 \%$ level of significance $\left(\beta_{1}=0.103\right.$, t-stat $\left.=2.89\right)$. It indicates that a $1 \%$ increase in overall foreign institutional equity participation is likely to 
increase investment efficiency by $0.103 \%$. This empirical result supports our Hypothesis 1 that an increase in foreign institutional participation improves investment efficiency among ASEAN-3 countries.

Table 5. Regression results of foreign institutional participation and its types on investment efficiency.

\begin{tabular}{|c|c|c|c|c|c|c|c|c|c|}
\hline \multirow{3}{*}{ Variables } & \multirow{2}{*}{\multicolumn{3}{|c|}{ Basic Models }} & \multirow{2}{*}{\multicolumn{3}{|c|}{$\begin{array}{c}\text { Endogeneity of Foreign Institutional } \\
\text { Ownership }\end{array}$}} & \multirow{2}{*}{\multicolumn{3}{|c|}{ Robust Check }} \\
\hline & & & & & & & & & \\
\hline & (1) & (2) & (3) & (4) & (5) & (6) & (7) & (8) & (9) \\
\hline F_INST & $\begin{array}{c}0.103^{* * *} \\
(2.89)\end{array}$ & & & $\begin{array}{c}0.945^{* * *} \\
(4.34)\end{array}$ & & & $\begin{array}{c}0.277^{* *} \\
(2.56)\end{array}$ & & \\
\hline FINST_PR & & $\begin{array}{l}0.0711^{* *} \\
(2.09)\end{array}$ & & & $\begin{array}{l}0.0991 \text { ** } \\
(2.57)\end{array}$ & & & $\begin{array}{l}0.0772 \text { ** } \\
(2.08)\end{array}$ & \\
\hline FINST_PS & & & $\begin{array}{c}0.00693 \\
(0.16)\end{array}$ & & & $\begin{array}{l}0.2209 * * \\
(2.25)\end{array}$ & & & $\begin{array}{c}0.0444 \\
(1.00)\end{array}$ \\
\hline $\mathrm{FCF}$ & $\begin{array}{c}0.172 * * * \\
(6.37)\end{array}$ & $\begin{array}{c}0.285^{* * *} \\
(12.83)\end{array}$ & $\begin{array}{l}0.141^{* * *} \\
(6.71)\end{array}$ & $\begin{array}{c}0.151 * * * \\
(12.51)\end{array}$ & $\begin{array}{c}0.245^{* * *} \\
(37.70)\end{array}$ & $\begin{array}{c}0.174^{* * *} \\
(18.89)\end{array}$ & $\begin{array}{c}0.149 * * * \\
(5.23)\end{array}$ & $\begin{array}{c}0.230 * * * \\
(8.37)\end{array}$ & $\begin{array}{c}0.119 * * * \\
(5.66)\end{array}$ \\
\hline A_TAN & $\begin{array}{c}0.369^{* * *} \\
(16.25)\end{array}$ & $\begin{array}{c}-0.0726 * * * \\
(-7.64)\end{array}$ & $\begin{array}{c}-0.0503^{* * *} \\
(-3.44)\end{array}$ & $\begin{array}{c}0.346 \text { *** } \\
(45.51)\end{array}$ & $\begin{array}{c}-0.0339 * * * \\
(-13.81)\end{array}$ & $\begin{array}{c}-0.0293 * * * \\
(-4.98)\end{array}$ & $\begin{array}{c}0.308 * * * \\
(9.98)\end{array}$ & $\begin{array}{c}-0.0553 * * * \\
(-4.87)\end{array}$ & $\begin{array}{c}-0.0437 * * \\
(-2.54)\end{array}$ \\
\hline SLACK & $\begin{array}{l}-0.00344 \\
* * * \\
(-4.76)\end{array}$ & $\begin{array}{c}-0.00178 * \\
(-1.87)\end{array}$ & $\begin{array}{c}-0.000341 \\
(-0.99)\end{array}$ & $\begin{array}{l}-0.0032 * * * \\
(-6.76)\end{array}$ & $\begin{array}{c}0.000623 \text { * } \\
(1.71)\end{array}$ & $\begin{array}{c}-0.00035 \\
(-0.87)\end{array}$ & $\begin{array}{l}-0.0030 * * * \\
(-2.83)\end{array}$ & $\begin{array}{c}0.0009 \\
(1.06)\end{array}$ & $\begin{array}{l}-0.00058 \\
(-1.02)\end{array}$ \\
\hline ORC & $\begin{array}{c}-0.0612 * \\
(-1.87)\end{array}$ & $\begin{array}{c}0.0296 \\
(0.85)\end{array}$ & $\begin{array}{c}0.0465 \\
(1.32)\end{array}$ & $\begin{array}{c}0.0352 \\
(1.32)\end{array}$ & $\begin{array}{c}0.0221 \text { * } \\
(1.78)\end{array}$ & $\begin{array}{c}0.0682 * * * \\
(3.17)\end{array}$ & & & \\
\hline DIV & $\begin{array}{l}-0.00899 * * \\
(-2.12)\end{array}$ & $\begin{array}{l}-0.00817 \\
* * * \\
(-2.80)\end{array}$ & $\begin{array}{l}-0.0106 \text { ** } \\
(-2.54)\end{array}$ & $\begin{array}{l}-0.0077^{* *} \\
(-2.40)\end{array}$ & $\begin{array}{l}-0.00983 \\
* * * \\
(-6.63)\end{array}$ & $\begin{array}{l}-0.0076^{* * *} \\
(-2.93)\end{array}$ & & & \\
\hline F_LEV & $\begin{array}{c}-0.0440 \text { ** } \\
(-2.32)\end{array}$ & $\begin{array}{l}0.0000174 \\
(0.33)\end{array}$ & $\begin{array}{c}-0.00233 \\
(-1.38)\end{array}$ & $\begin{array}{l}0.0589 * * * \\
(6.40)\end{array}$ & $\begin{array}{c}-0.00114 \\
(-0.30)\end{array}$ & $\begin{array}{c}0.0002 \\
(0.03)\end{array}$ & & & \\
\hline SIZE & $\begin{array}{l}-0.0517 * * * \\
\quad(-4.24)\end{array}$ & $\begin{array}{c}-0.0160 * \\
(-1.73)\end{array}$ & $\begin{array}{c}0.0103 \\
(0.77)\end{array}$ & $\begin{array}{c}-0.0296^{* * *} \\
(4.88)\end{array}$ & $\begin{array}{c}-0.00848 \\
* * * \\
(-6.49)\end{array}$ & $\begin{array}{c}0.00115 \\
(0.18)\end{array}$ & $\begin{array}{c}-0.127^{* * *} \\
(-5.84)\end{array}$ & $\begin{array}{c}-0.0390 * * * \\
(-4.57)\end{array}$ & $\begin{array}{l}-0.0044 \\
(-0.29)\end{array}$ \\
\hline FIN_LEV & & & & & & & $\begin{array}{c}0.564^{* * *} \\
(3.13)\end{array}$ & $\begin{array}{c}-0.0043^{* *} \\
(-2.39)\end{array}$ & $\begin{array}{l}-0.0153 \\
(-0.59)\end{array}$ \\
\hline LOSS & & & & & & & $\begin{array}{c}0.194^{* * *} \\
(2.99)\end{array}$ & $\begin{array}{l}0.0047 \\
(1.59)\end{array}$ & $\begin{array}{c}0.0065 * \\
(1.75)\end{array}$ \\
\hline REV & & & & & & & $\begin{array}{c}-0.0311 \text { ** } \\
(-2.27)\end{array}$ & $\begin{array}{c}-0.0169 * * * \\
(-2.76)\end{array}$ & $\begin{array}{c}-0.0098 \text { * } \\
(-1.96)\end{array}$ \\
\hline Intercept & $\begin{array}{c}0.134^{* *} \\
(2.01)\end{array}$ & $\begin{array}{c}0.124^{* *} \\
(2.42)\end{array}$ & $\begin{array}{l}-0.0345 \\
(-0.50)\end{array}$ & $\begin{array}{c}0.00122 \\
(0.03)\end{array}$ & $\begin{array}{c}0.0662^{* * *} \\
(10.54)\end{array}$ & $\begin{array}{l}-0.0181 \\
(-0.47)\end{array}$ & $\begin{array}{c}0.0483^{* * *} \\
(4.66)\end{array}$ & $\begin{array}{l}0.272 * * * \\
(5.45)\end{array}$ & $\begin{array}{c}0.0465 \\
(0.55)\end{array}$ \\
\hline Obs. & 4468 & 4142 & 1622 & 5465 & 4474 & 2663 & 4547 & 3295 & 1790 \\
\hline $\mathrm{F}$ & $35.91^{* * *}$ & $35.11^{* * *}$ & $4.56^{* * *}$ & $310.11 * * *$ & $301.24^{* * *}$ & $27.94^{* * *}$ & & & \\
\hline R-squared & 0.3683 & 0.3004 & 0.1317 & 0.3463 & 0.3505 & 0.1739 & & & \\
\hline Hansen J & & & & & & & 55.91 & 151.12 & 93.84 \\
\hline ( $p$-value $)$ & & & & & & & 0.330 & 0.198 & 0.485 \\
\hline Wald F & & & & & & & 294.75 & 236.43 & 72.98 \\
\hline $\mathrm{P}(\mathrm{AR} 1)$ & & & & & & & 0.000 & 0.000 & 0.000 \\
\hline $\mathrm{P}(\mathrm{AR} 2)$ & & & & & & & 0.220 & 0.283 & 0.375 \\
\hline
\end{tabular}

${ }^{* * *} p<0.001,{ }^{* *} p<0.05,{ }^{*} p<0.10$ (t-statistics are in parentheses). This table reports the regression results for overall foreign institutional equity participation and its types on investment efficiency. Columns 1 to 3 report the regression results of the basic Model 2, using robust standard errors clustered at the firm level to address the heteroskedasticity and autocorrelation concerns with the year and firm fixed effects. Columns 4 to 6 report the results of second-stage instrumental variables (IV) to address the potential endogeneity of foreign institutional equity participation. In the first-stage regression (unreported), we regressed F_INST on market value and turnover (instrumental variables), along with cash flow (CF) and TobinQ (TQ) by incorporating year, country, and industry fixed effects. In the second-stage regression, we replaced foreign institutional equity participation with the fitted values of the first-stage regression. Columns 7 to 9 show the results of the generalized method of moments (GMM) with year, country, and industry fixed effects. See Table 1 for variable definitions and measurements. 
Column (2) shows that FINST_PR has a positive and significant relation with INV_EF at a $5 \%$ level of significance $\left(\beta_{1}=0.0711\right.$, t-stat $\left.=2.09\right)$. It indicates that a $1 \%$ increase in foreign institutional pressure-resistant equity participation is likely to increase investment efficiency by $0.0711 \%$. This empirical result supports Hypothesis $1 \mathrm{a}$ that an increase in foreign institutional pressure-resistant equity participation rallies investment efficiency among the ASEAN-3 countries. However, Column (3) reports that FINST_PS has a positive but insignificant relation with INV_EF $(\mathrm{t}$-stat $=0.16)$.

We address the potential endogeneity issue that may confound the estimations. Columns 4,5 , and 6 of Table 5 represent the second-stage instrumental variable (IV) regression results to address the potential endogeneity of foreign institutional equity participation. We used market value (MV), measured as the natural logarithm of market capitalization, and turnover, calculated as the ratio of annual sales to floating shares, as instrumental variables, as suggested by Cao et al. [1]. In the first-stage regression (unreported), we regressed F_INST on market value and turnover (instrumental variables) along with cash flow (CF) and TobinQ (TQ) by incorporating year, country, and industry fixed effects. In the second-stage regression, we replaced foreign institutional equity participation with the fitted values of the first-stage regression. The empirical results of Columns 4 and 5 are consistent with our earlier results, as depicted in Columns 1 and 2, respectively. This consistency suggests that foreign institutional equity participation and pressure-resistant institutional equity participation are positively associated with firm investment efficiency. However, the impact of foreign institutional pressure-sensitive ownership (Column 6) also correlates with investment efficiency at a 5\% level of significance when we controlled for endogeneity by using the instrumental variable (IV) approach. The empirical results of the control variables are aligned and consistent with previous studies $[4,9,15]$.

\subsection{Robustness Check}

We ensured the robustness of the empirical results of Equation (2) using the generalized method of moments (GMM) by changing the proxies for existing control variables and incorporating some new control variables into Equation (2) in Columns 7, 8, and 9 (Table 5). To control the reverse causality of the potential endogenous variable, that is, foreign institutional ownership, we took a one-lagged value of the endogenous variable. The empirical results in Columns 7, 8, and 9 in Table 5 align with the basic models and previous empirical findings. To identify the exogenous instrumental variables, we performed the SarganHansen overidentifying restriction test, following Labra and Torrecillas [50], who state that the $p$-value of Hansen's J between 0.05 and 0.80 means the test's asymptotic properties have been applied. The Hanson's J p-value for overall foreign institutional ownership, foreign institutional pressure-resistant, and foreign institutional pressure-sensitive investors is $0.33,0.19$, and 0.48 , respectively, indicating the validity of instruments and the consistency of estimates. Further, the Wald F-statistics values (294.75 and 236.43) of overall foreign institutional equity participation and foreign institutional pressure-resistant ownership, respectively, support the rationale to reject the null hypothesis that instrumental variables are weak. Moreover, we also checked the robustness of the basic model using different proxies (untabulated results) for investment efficiency and found comparable results.

Table 6 explains the impact of varying foreign institutional equity participation levels on investment efficiency. Following Chen et al. [2], we used continuous (overall foreign institutional equity ownership comprising all levels) and five dummy variables: (1) D > $\%$, (2) $\mathrm{D}>5 \%$, (3) D > 10\%, (4) D > 20\%, and (5) D > 30\%. Our empirical results for overall foreign institutional ownership depict that it has a positive and highly significant impact on investment efficiency at all levels except $\mathrm{D}>0$. This indicates that as the level of overall institutional foreign ownership increases, the investment efficiency also increases. Our results for overall foreign institutional ownership also show that the optimal level of foreign ownership is where D $>20 \%$, as supported by the higher value of the $t$-statistic and the R-square $(3.81,0.3415)$. The empirical results of the control variables have remained consistent with the results of prior empirical studies. 
Table 6. Regression results of the impact of varying levels of overall foreign institutional ownership.

\begin{tabular}{|c|c|c|c|c|c|c|}
\hline \multirow{3}{*}{ Variables } & \multicolumn{6}{|c|}{ Overall Foreign Institutional Equity Participation } \\
\hline & Continuous F_INST & $\mathrm{D}>0 \%$ & $\mathrm{D}>5 \%$ & $\mathrm{D}>10 \%$ & $\mathrm{D}>20 \%$ & $\mathrm{D}>30 \%$ \\
\hline & (1) & (2) & (3) & (4) & (5) & (6) \\
\hline \multirow{2}{*}{ F_INST } & $0.103^{* * *}$ & 0.00446 & $0.0103^{* * *}$ & $0.0126^{* *}$ & $0.0334^{* * *}$ & $0.0416^{* * *}$ \\
\hline & $(2.98)$ & $(0.64)$ & $(2.60)$ & $(2.50)$ & $(3.81)$ & $(3.10)$ \\
\hline \multirow{2}{*}{ FCF } & $0.172 * * *$ & $0.162 * * *$ & $0.162 * * *$ & $0.162 * * *$ & $0.162^{* * *}$ & $0.162^{* * *}$ \\
\hline & $(13.45)$ & $(12.44)$ & $(12.43)$ & $(12.48)$ & (12.48) & 12.49 \\
\hline \multirow{2}{*}{ A_TAN } & $0.369^{* * *}$ & $0.340^{* * *}$ & $0.341^{* * *}$ & $0.341^{* * *}$ & $0.340^{* * *}$ & $0.339^{* * *}$ \\
\hline & $(42.41)$ & (39.78) & $(39.89)$ & $(39.88)$ & (39.97) & 39.84 \\
\hline \multirow{2}{*}{ SLACK } & $-0.0034^{* * *}$ & $-0.0037^{* * *}$ & $-0.0033^{* * *}$ & $-0.0032^{* * *}$ & $-0.0032^{* * *}$ & $-0.0031^{* * *}$ \\
\hline & $(-6.45)$ & $(-6.02)$ & $(-6.05)$ & $(-6.03)$ & $(-6.08)$ & -5.86 \\
\hline \multirow{2}{*}{ ORC } & $-0.0612 * *$ & -0.0163 & -0.0168 & -0.0167 & -0.015 & -0.146 \\
\hline & $(-2.06)$ & $(-0.54)$ & $(-0.56)$ & $(-0.56)$ & $(-0.52)$ & -0.49 \\
\hline \multirow{2}{*}{ DIV } & $-0.00899 * *$ & $-0.0133^{* * *}$ & $-0.0132^{* * *}$ & $-0.0131^{* * *}$ & $0.0130^{* * *}$ & $-0.013^{* * *}$ \\
\hline & $(-2.52)$ & $(-3.68)$ & $(-3.64)$ & $(-3.62)$ & $(-3.61)$ & -3.60 \\
\hline \multirow{2}{*}{ F_LEV } & $-0.0440^{* * *}$ & $-0.0474^{* * *}$ & $-0.0458^{* * *}$ & $-0.0471^{* * *}$ & $-0.046^{* * *}$ & $-0.0468^{* * *}$ \\
\hline & $(-4.26)$ & $(-4.49)$ & $(-4.34)$ & $(-4.47)$ & $(-4.460)$ & -4.45 \\
\hline \multirow{2}{*}{ SIZE } & $-0.0517^{* * *}$ & $-0.0258^{* * *}$ & $-0.0277^{* * *}$ & $-0.0268^{* * *}$ & $-0.0260^{* * *}$ & $-0.0268^{* * *}$ \\
\hline & $(-6.99)$ & $(-3.58)$ & $(-3.84)$ & $(-3.74)$ & $(-3.64)$ & -3.75 \\
\hline \multirow{2}{*}{ Intercept } & $0.134^{* * *}$ & 0.0332 & 0.0439 & 0.0405 & 0.0358 & 0.412 \\
\hline & $(3.34)$ & $(0.84)$ & $(1.11)$ & $(1.02)$ & $(0.91)$ & 1.04 \\
\hline \multirow{2}{*}{ Obs. $\mathrm{R}^{2}$} & 4468 & 4468 & 4468 & 4468 & 4468 & 4468 \\
\hline & 0.3683 & 0.3390 & 0.3401 & 0.3400 & 0.3415 & 0.3406 \\
\hline
\end{tabular}

${ }^{* * *} p<0.001,{ }^{* *} p<0.05,{ }^{*} p<0.10$ (t-statistics are in parentheses). This table reports within regression estimates with year and firm fixed effects.

Table 7 explains the impact of varying levels of foreign institutional pressure-resistant equity participation on investment efficiency. Our empirical results depict that it has a positive and significant impact on investment efficiency only at D $>10 \%$. The rest of the levels do not have a significant impact on the investment efficiency of domestic firms. The increase in institutional foreign pressure-resistant ownership beyond $20 \%$ has a positive but insignificant impact. Our results for foreign institutional pressure-resistant equity ownership show that the optimal level of foreign pressure-resistant ownership is when $\mathrm{D}>10 \%$, as supported by the higher value of the t-statistic and the R-square $(2.30,0.3002)$. The empirical results of the control variables have remained consistent with the results of prior empirical studies.

Table 8 explains the impact of varying levels of foreign institutional pressure-sensitive equity participation on investment efficiency. The empirical results describe that it has a positive and significant impact on investment efficiency only at D >10\% (at a 10\% level of significance). However, it has a negative impact when its level goes beyond $\mathrm{D}>30 \%$. The rest of the levels do not have a significant impact on the investment efficiency of domestic firms. Our results for foreign institutional pressure-sensitive equity ownership show that the optimal level of foreign pressure-sensitive ownership is when D $>10 \%$, as supported by the higher value of the t-statistic and the R-square $(1.71,0.1337)$. The empirical results of the control variables have remained consistent with the results of prior empirical studies. 
Table 7. Regression results of the impact of varying levels of foreign institutional pressure-resistant ownership.

\begin{tabular}{|c|c|c|c|c|c|c|}
\hline \multirow{3}{*}{ Variables } & \multicolumn{6}{|c|}{ Pressure-Resistant Foreign Institutional Equity Participation } \\
\hline & Continuous FINST_PR & $\mathrm{D}>0 \%$ & $\mathrm{D}>5 \%$ & $\mathrm{D}>10 \%$ & $\mathrm{D}>20 \%$ & $\mathrm{D}>30 \%$ \\
\hline & (1) & (2) & (3) & (4) & (5) & (6) \\
\hline FINST_PS & $\begin{array}{c}0.0709 * * \\
(2.52)\end{array}$ & $\begin{array}{c}0.000495 \\
(0.12)\end{array}$ & $\begin{array}{c}0.00256 \\
(1.02)\end{array}$ & $\begin{array}{c}0.00794^{* *} \\
2.30\end{array}$ & $\begin{array}{c}0.0052 \\
0.84\end{array}$ & $\begin{array}{c}0.005 \\
0.36\end{array}$ \\
\hline $\mathrm{FCF}$ & $\begin{array}{c}0.285^{* * *} \\
(30.86)\end{array}$ & $\begin{array}{c}0.286^{* * *} \\
(30.86)\end{array}$ & $\begin{array}{c}0.285 * * * \\
(30.84)\end{array}$ & $\begin{array}{c}0.2857^{* * *} \\
30.90\end{array}$ & $\begin{array}{c}0.285^{* * *} \\
30.86\end{array}$ & $\begin{array}{c}0.285^{* * *} \\
30.86\end{array}$ \\
\hline A_TAN & $\begin{array}{c}-0.0726 * * * \\
(-15.86)\end{array}$ & $\begin{array}{c}-0.0735 * * * \\
(-16.08)\end{array}$ & $\begin{array}{c}-0.0734^{* * *} \\
(-16.06)\end{array}$ & $\begin{array}{c}-0.0731 * * * \\
-16.01\end{array}$ & $\begin{array}{c}-0.0733^{* * *} \\
-16.05\end{array}$ & $\begin{array}{c}-0.0734^{* * *} \\
16.07\end{array}$ \\
\hline SLACK & $\begin{array}{c}-0.0018^{* * *} \\
(-3.08)\end{array}$ & $\begin{array}{c}-0.0017^{* * *} \\
(-3.10)\end{array}$ & $\begin{array}{c}-0.0018^{* * *} \\
(-3.10)\end{array}$ & $\begin{array}{c}-0.00179^{* * *} \\
-3.12\end{array}$ & $\begin{array}{c}-0.00178^{* * *} \\
-3.09\end{array}$ & $\begin{array}{c}-0.00178^{* * *} \\
-3.10\end{array}$ \\
\hline ORC & $\begin{array}{c}0.0295 \\
(1.28)\end{array}$ & $\begin{array}{c}0.0323 \\
(1.40)\end{array}$ & $\begin{array}{c}0.0321 \\
(1.40)\end{array}$ & $\begin{array}{c}0.0309 \\
1.35\end{array}$ & $\begin{array}{c}0.0322 \\
1.40\end{array}$ & $\begin{array}{c}0.0324 \\
1.41\end{array}$ \\
\hline DIV & $\begin{array}{c}-0.00817^{* * *} \\
(-3.21)\end{array}$ & $\begin{array}{c}-0.00843^{* * *} \\
(-3.31)\end{array}$ & $\begin{array}{c}-0.0084^{* * *} \\
(-3.30)\end{array}$ & $\begin{array}{c}-0.0082 \text { *** } \\
-3.24\end{array}$ & $\begin{array}{c}-0.00834^{* * *} \\
-3.28\end{array}$ & $\begin{array}{c}-0.0084^{* * *} \\
-3.31\end{array}$ \\
\hline F_LEV & $\begin{array}{c}0.0000169 \\
(0.02)\end{array}$ & $\begin{array}{c}-0.0000555 \\
(-0.07)\end{array}$ & $\begin{array}{c}-0.0000275 \\
(-0.03)\end{array}$ & $\begin{array}{c}0.00001 \\
0.01\end{array}$ & $\begin{array}{c}-0.000039 \\
-0.05\end{array}$ & $\begin{array}{c}-0.000045 \\
-0.05\end{array}$ \\
\hline SIZE & $\begin{array}{c}-0.0160^{* * *} \\
(-3.20)\end{array}$ & $\begin{array}{c}-0.0126^{* *} \\
(-2.58)\end{array}$ & $\begin{array}{c}-0.0134^{* * *} \\
(-2.74)\end{array}$ & $\begin{array}{c}-0.0142^{* * *} \\
-2.92\end{array}$ & $\begin{array}{c}-0.126 * * * \\
-2.62\end{array}$ & $\begin{array}{c}-0.124^{* *} \\
-2.59\end{array}$ \\
\hline Intercept & $\begin{array}{c}0.124^{* * *} \\
(4.39)\end{array}$ & $\begin{array}{c}0.107^{* * *} \\
(3.90)\end{array}$ & $\begin{array}{c}0.112 * * * \\
(4.02)\end{array}$ & $\begin{array}{c}0.115^{* * *} \\
4.18\end{array}$ & $\begin{array}{c}0.1079 * * * \\
3.92\end{array}$ & $\begin{array}{c}0.1072 * * * \\
3.90\end{array}$ \\
\hline Obs. $R^{2}$ & $\begin{array}{c}4142 \\
0.3004\end{array}$ & $\begin{array}{c}4142 \\
0.2991\end{array}$ & $\begin{array}{c}4142 \\
0.2993\end{array}$ & $\begin{array}{c}4142 \\
0.3002\end{array}$ & $\begin{array}{c}4142 \\
0.2993\end{array}$ & $\begin{array}{c}4142 \\
0.2992\end{array}$ \\
\hline
\end{tabular}

*** $p<0.001,{ }^{* *} p<0.05,{ }^{*} p<0.10$ (t-statistics are in parentheses). This table reports within regression estimates with year and firm fixed effects.

Table 8. Regression results of the impact of varying levels of foreign institutional pressure-sensitive ownership.

\begin{tabular}{|c|c|c|c|c|c|c|}
\hline \multirow{3}{*}{ Variables } & \multicolumn{6}{|c|}{ Pressure-Sensitive Foreign Institutional Equity Participation } \\
\hline & Continuous FINST_PS & $\mathrm{D}>0 \%$ & $\mathrm{D}>5 \%$ & $\mathrm{D}>10 \%$ & $\mathrm{D}>\mathbf{2 0} \%$ & $\mathrm{D}>30 \%$ \\
\hline & (1) & $(2)$ & (3) & (4) & (5) & (6) \\
\hline FINST_PS & $\begin{array}{c}0.00693 \\
(0.23)\end{array}$ & $\begin{array}{c}0.00149 \\
(0.25)\end{array}$ & $\begin{array}{c}0.00565 \\
(0.88)\end{array}$ & $\begin{array}{c}0.0127 \text { * } \\
(1.71)\end{array}$ & $\begin{array}{c}0.0193 \\
1.37\end{array}$ & $\begin{array}{c}-0.00037 \\
-0.04\end{array}$ \\
\hline FCF & $\begin{array}{c}0.141 * * * \\
(11.40)\end{array}$ & $\begin{array}{c}0.141 * * * \\
(11.40)\end{array}$ & $\begin{array}{c}0.141^{* * * *} \\
(11.34)\end{array}$ & $\begin{array}{c}0.140^{* * * *} \\
(11.30)\end{array}$ & $\begin{array}{c}0.1435^{* * *} \\
11.67\end{array}$ & $\begin{array}{c}0.1411^{* * *} \\
11.47\end{array}$ \\
\hline A_TAN & $\begin{array}{c}-0.0503^{* * *} \\
(-4.99)\end{array}$ & $\begin{array}{c}-0.0502 * * * \\
(-4.98)\end{array}$ & $\begin{array}{c}-0.0503^{* * *} \\
(-4.99)\end{array}$ & $\begin{array}{c}-0.0505^{* * *} \\
(-5.02)\end{array}$ & $\begin{array}{c}-0.0444 \text { *** } \\
-4.60\end{array}$ & $\begin{array}{c}-0.0444^{* * *} \\
-4.59\end{array}$ \\
\hline SLACK & $\begin{array}{c}-0.000341 \\
(-0.72)\end{array}$ & $\begin{array}{c}-0.000337 \\
(-0.72)\end{array}$ & $\begin{array}{c}-0.000346 \\
(-0.74)\end{array}$ & $\begin{array}{c}-0.000340 \\
(-0.72)\end{array}$ & $\begin{array}{c}-0.00489 \\
-1.05\end{array}$ & $\begin{array}{c}-0.00047 \\
-1.01\end{array}$ \\
\hline ORC & $\begin{array}{l}0.0465 \\
(1.57)\end{array}$ & $\begin{array}{l}0.0465 \\
(1.57)\end{array}$ & $\begin{array}{c}0.0463 \\
(1.57)\end{array}$ & $\begin{array}{l}0.0449 \\
(1.52)\end{array}$ & $\begin{array}{c}0.0368 \\
1.28\end{array}$ & $\begin{array}{c}0.03789 \\
1.31\end{array}$ \\
\hline DIV & $\begin{array}{c}-0.0106^{* * *} \\
(-2.96)\end{array}$ & $\begin{array}{c}-0.0106^{* * *} \\
(-2.96)\end{array}$ & $\begin{array}{c}-0.0107^{* * *} \\
(-2.97)\end{array}$ & $\begin{array}{c}-0.0105^{* * *} \\
(-2.92)\end{array}$ & $\begin{array}{c}-0.0096^{* * *} \\
-2.73\end{array}$ & $\begin{array}{c}-0.0096^{* * *} \\
-2.72\end{array}$ \\
\hline F_LEV & $\begin{array}{c}-0.00233 \\
(-1.42)\end{array}$ & $\begin{array}{c}-0.00231 \\
(-1.41)\end{array}$ & $\begin{array}{c}-0.00217 \\
(-1.31)\end{array}$ & $\begin{array}{c}-0.00239 \\
(-1.46)\end{array}$ & $\begin{array}{c}-0.00275^{*} \\
-1.69\end{array}$ & $\begin{array}{c}-0.00271 * \\
-1.66\end{array}$ \\
\hline SIZE & $\begin{array}{l}0.0103 \\
(1.28)\end{array}$ & $\begin{array}{c}0.0104 \\
(1.29)\end{array}$ & $\begin{array}{l}0.0108 \\
(1.34)\end{array}$ & $\begin{array}{l}0.0114 \\
(1.41)\end{array}$ & $\begin{array}{c}0.00502 \\
0.69\end{array}$ & $\begin{array}{c}0.0053 \\
0.72\end{array}$ \\
\hline Intercept & $\begin{array}{l}-0.0345 \\
(-0.81)\end{array}$ & $\begin{array}{l}-0.0356 \\
(-0.83)\end{array}$ & $\begin{array}{l}-0.0386 \\
(-0.90)\end{array}$ & $\begin{array}{l}-0.0418 \\
(-0.98)\end{array}$ & $\begin{array}{c}-0.0084 \\
-0.21\end{array}$ & $\begin{array}{c}-0.0076 \\
-0.19\end{array}$ \\
\hline Obs. $R^{2}$ & $\begin{array}{c}1622 \\
0.1317\end{array}$ & $\begin{array}{c}1622 \\
0.1318\end{array}$ & $\begin{array}{c}1622 \\
0.1323\end{array}$ & $\begin{array}{c}1622 \\
0.1337\end{array}$ & $\begin{array}{c}1622 \\
0.1294\end{array}$ & $\begin{array}{c}1622 \\
0.1252\end{array}$ \\
\hline
\end{tabular}

${ }^{* * *} p<0.001,{ }^{* *} p<0.05,{ }^{*} p<0.10$ (t-statistics are in parentheses). This table reports within regression estimates with year and firm fixed effects. 
Table 9 reports the evidence of directional causality. We rejected the null hypothesis that there is no Granger causality between the dependent variable and explanatory variables. The results are based upon a lag order of 3 . The empirical results show that there is unidirectional causality from foreign institutional equity participation to investment efficiency. However, there is no causality from investment efficiency to foreign institutional equity participation. Free cash flows, asset tangibility, dividends, and firm size have bidirectional causality with investment efficiency. However, other receivables claimant (ORC) and financial leverage have unidirectional causality from investment efficiency.

Table 9. Vector Error Correction (VEC) Granger causality/block exogeneity Wald test.

\begin{tabular}{cccccccccc}
\hline Variables & D(INV_EF) & D(F_INST) & D(FCF) & D(A_TAN) & D(SLACK) & D(ORC) & D(DIV) & D(F_LEV) & D(SIZE) \\
\hline \multirow{2}{*}{ D(INV_EF) } & - & 8.315 & 19.984 & 82.357 & 2.776 & 3.528 & 12.229 & 1.706 & 57.360 \\
& & $(0.040)$ & $(0.000)$ & $(0.000)$ & $(0.428)$ & $(0.317)$ & $(0.007)$ & $(0.636)$ & $(0.000)$ \\
\hline \multirow{2}{*}{ D(F_INST) } & 3.020 & & 0.197 & 5.730 & 1.548 & 6.509 & 3.861 & 0.875 & 6.766 \\
& $(0.389)$ & - & $(0.978)$ & $(0.126)$ & $(0.671)$ & $(0.089)$ & $(0.277)$ & $(0.831)$ & $(0.080)$ \\
\hline \multirow{2}{*}{ D(FCF) } & 12.380 & 0.623 & & 2.853 & 7.560 & 0.399 & 41.513 & 14.236 & 8.529 \\
& $(0.006)$ & $(0.891)$ & - & $(0.415)$ & $(0.056)$ & $(0.941)$ & $(0.000)$ & $(0.003)$ & $(0.036)$ \\
\hline \multirow{2}{*}{ D(A_TAN) } & 24.015 & 0.680 & 21.940 & - & 4.230 & 13.271 & 16.180 & 12.046 & 79.811 \\
& $(0.000)$ & $(0.878)$ & $(0.000)$ & & $(0.238)$ & $(0.004)$ & $(0.001)$ & $(0.007)$ & $(0.000)$ \\
\hline \multirow{2}{*}{ D(SLACK) } & 0.649 & 20.982 & 1.296 & 0.883 & & 3.811 & 1.521 & 1.011 & 2.051 \\
& $(0.885)$ & $(0.000)$ & $(0.730)$ & $(0.830)$ & & $(0.283)$ & $(0.677)$ & $(0.799)$ & $(0.562)$ \\
\hline \multirow{2}{*}{ D(ORC) } & 10.005 & 0.316 & 6.573 & 12.332 & 11.977 & & 1.451 & 5.201 & 35.382 \\
& $(0.019)$ & $(0.957)$ & $(0.087)$ & $(0.006)$ & $(0.008)$ & - & $(0.694)$ & $(0.158)$ & $(0.000)$ \\
\hline \multirow{2}{*}{ D(DIV) } & 11.671 & 5.485 & 18.995 & 11.792 & 0.294 & 0.520 & - & 5.883 & 53.084 \\
& $(0.009)$ & $(0.140)$ & $(0.000)$ & $(0.008)$ & $(0.961)$ & $(0.915)$ & $(0.118)$ & $(0.000)$ \\
\hline \multirow{2}{*}{ D(F_LEV) } & 7.090 & 3.834 & 16.235 & 5.220 & 2.035 & 15.261 & 4.504 & $(0.212)$ & - \\
\hline \multirow{2}{*}{ D(SIZE) } & $(0.069)$ & $(0.280)$ & $(0.001)$ & $(0.156)$ & $(0.565)$ & $(0.002)$ & 26.939 \\
& 7.892 & 1.254 & 0.384 & 5.231 & 8.251 & 9.490 & 17.478 & 10.243 \\
\hline
\end{tabular}

$p$-values are reported in the parenthesis for the chi-square test values.

\section{Discussion}

This study investigated the impact of overall foreign institutional equity participation on corporate investment efficiency. We segregated the overall foreign institutional equity participation into its two types, comprising pressure-resistant and pressure-sensitive investors, to examine their impact on domestic firms' investment efficiency. We also examined the impact of varying levels of foreign institutional equity participation and its types on investment efficiency among selected ASEAN-3 countries.

The empirical findings portray several inferences. Our results suggest that overall foreign institutional equity participants play a significant role in enhancing the domestic firms' investment efficiency because of their influential and monitoring roles that exert pressure on corporate insiders. Consequently, foreign institutional equity participants ${ }^{\prime}$ monitoring capabilities induce innovations, risk-taking, and efficient utilization of financial resources, as suggested by the previous studies of Aggarwal et al. [21] and Cella [18]. These results are in line with Hypothesis 1 . The segregation of overall foreign institutional equity participation provides further insights into the role of foreign institutional pressureresistant and pressure-sensitive equity participants on firm investment efficiency. Being active investors with fewer business ties and regulatory restrictions, foreign institutional pressure-resistant equity investors exert extensive monitoring on firms' executive actions. This is why the empirical results of the impact of foreign overall institutional and pressureresistant equity investors' on investment efficiency look alike and have remained consistent. Theoretically, our results support the notion that overall foreign institutional and pressure- 
resistant equity investors exert effective monitoring to reduce agency cost and mitigate information asymmetries by controlling moral hazard issues of adverse selection of capital investment projects, thereby enhancing investment efficiency.

However, the foreign institutional pressure-sensitive investors, being passive shareholders with close business ties with their portfolio firms, seem to be more loyal to corporate management by sidestepping conflicting and controversial managerial actions. They usually do not raise their voice in management because of their short-termism aptitude. Our empirical results support this notion, as depicted by their positive but insignificant impact on firm investment efficiency. These results are in line with our Hypotheses 1a and 1b. These results are consistent with the previous findings of Cao et al. [1] and Ferreira and Matos [24]

We also addressed the impact of varying levels of overall foreign institutional equity participation and its two types on investment efficiency. Our empirical results for overall foreign institutional ownership show a positive and highly significant impact on investment efficiency when it is greater than $5 \%$. However, its impact decreases as it goes beyond $10 \%$ and again increases (highly significant) when it goes beyond $20 \%$. This indicates that as the level of overall institutional foreign ownership increases, the investment efficiency also increases. Our overall foreign institutional ownership results also show that the optimal level of foreign ownership is when D $>20 \%$. Foreign institutional pressureresistant ownership is positive and significant only when it is greater than $10 \%$. However, foreign institutional pressure-sensitive ownership has a positive but weak relationship with investment efficiency when its level is higher than $10 \%$. At D > 30\%, the foreign institutional pressure-sensitive equity participation negatively affects the investment efficiency, though it is insignificant. This result supports the theoretical belief that pressure-sensitive investors do not influence managerial decisions because of short-termism, narrow ties, and less stability.

Our results are generalizable to developing and emerging economies, especially where capital markets are in the transition phase from a closed and pre-industrial economy to open, industrialized, and global markets. These results are of particular interest to the South East Asian countries' regulatory authorities, the neighboring states, for formulating financial liberalization policies to attract more inflows via promoting foreign portfolio investment. These results have implications for corporate policymakers in devising a strategy for optimal foreign institutional equity participation. For domestic firms' stockholders, foreign institutional investors' presence will mitigate agency costs and reduce information asymmetry. Furthermore, foreign portfolio investors' presence also instigates the managers to rationalize the investment opportunities that will eventually reduce moral hazards resulting from an adverse selection of capital investment projects. Institutional equity investors' presence may provide domestic firms with innovative investment opportunities to cope with sustainable corporate investment challenges.

The study has a few limitations. This study primarily focused on domestic firms with the presence of foreign institutional equity participation. Firms with local institutional participation only remained neglected. The comparison of domestic firms' investment efficiency with and without the presence of foreign institutional equity participation may assist investors in making a rational decision for value maximization. Moreover, various proxies of investment efficiency have been used in the literature. We measured investment efficiency based on the investment expectation model proposed by Richardson's model [46], whereas alternate models may also be used as a relevant alternate measure for investment efficiency.

\section{Conclusions}

This study empirically investigated the impact of overall foreign institutional equity participation, its two types, and their varying levels on domestic firms' corporate investment efficiency in selected ASEAN-3 emerging economies. The empirical findings depict that overall foreign institutional ownership and foreign institutional pressure-resistant 
ownership have a positive and significant impact on corporate investment efficiency, whereas foreign institutional pressure-sensitive ownership has a positive but insignificant impact. When we divided the overall institutional foreign equity ownership and its two types into different percentages, we found a positive and significant impact of overall foreign institutional ownership on investment efficiency at all levels. An increase of foreign pressure-resistant institutional ownership enhances investment efficiency up to a certain level and becomes insignificant. However, we found a weak relationship of foreign institutional pressure-sensitive equity ownership with investment efficiency at all varying levels of investments. Theoretically, our results support the notion that overall foreign institutional and pressure-resistant equity investors enhance investment efficiency via effective monitoring by reducing agency cost and mitigating information asymmetries. The empirical findings of this study are consistent with prior studies. Our results have implications for policymakers, regulators, domestic firms with growth potentials, and foreign portfolio investors. These results are also generalizable to both developing and emerging economies that have the potential for attracting foreign equity inflows. The empirical findings of this study suggest that domestic firms and host countries can grow in an economically sustainable way by devising an appropriate strategy for facilitating foreign portfolio investments.

Author Contributions: This paper has been taken from the Ph.D. thesis of S.R. The supervisors, M.H.H. and F.Z., have contributed to the paper's data analysis, writing review, and editing. All authors have read and agreed to the published version of the manuscript.

Funding: This research is supported by the University of Malaya Research Grant (UMRG) from Equitable Society Cluster, University of Malaya; Fund Code: RP060D-17SBS.

Institutional Review Board Statement: Not Applicable.

Informed Consent Statement: Not Applicable.

Data Availability Statement: The data has been captured from Bloomberg, Eikon Datastream, and the listed corporations' Annual Reports.

Acknowledgments: We are highly obliged to Hooy Chee (Universiti SAINS Malaysia), Rozaimah Zainudin (Universiti Malaya), and Robin K. Chou (National Chengchi University, Taiwan) for valuable suggestions on research methodology and rationales for the study. We extend our gratitude to the three anonymous referees for their valuable suggestions.

Conflicts of Interest: The authors declare no conflict of interest.

\section{References}

1. Cao, Y.; Dong, Y.; Lu, Y.; Ma, D. Does institutional ownership improve firm investment efficiency? Emerg. Mark. Financ. Trade 2020, 56, 2772-2792. [CrossRef]

2. Chen, R.; El Ghoul, S.; Guedhami, O.; Wang, H. Do state and foreign ownership affect investment efficiency? Evidence from privatizations. J. Corp. Financ. 2017, 42, 408-421. [CrossRef]

3. Sakawa, H.; Watanabel, N. Institutional ownership and firm performance under stakeholder-oriented corporate governance. Sustainability 2020, 12, 1021. [CrossRef]

4. Naeem, K.; Li, M.C. Corporate investment efficiency: The role of financial development in firms with financing constraints and agency issues in OECD non-financial firms. Int. Rev. Financ. Anal. 2019, 62, 53-68. [CrossRef]

5. Ratny, S.; Fonseka, M.M.; Tian, G.-L. Access to external financing and firm investment efficiency: Evidence from China. J. Dev. Areas 2019, 53, 109-122. [CrossRef]

6. MacCallum, R.C.; Browne, M.W.; Preacher, K.J. Comments on the Meehl-Waller (2002) procedure for appraisal of path analysis models. Psychol. Methods 2002, 7, 301-306. [CrossRef] [PubMed]

7. Myers, S.C.; Majluf, N.S. Corporate financing and investment decisions when firms have information that investors do not have. J. Financ. Econ. 1984, 13, 187-221. [CrossRef]

8. Jensen, M.C.; Meckling, W.H. Theory of the firm: Managerial behavior, agency costs and ownership structure. J. Financ. Econ. 1976, 3, 305-360. [CrossRef]

9. Guariglia, A.; Yang, J. A balancing act: Managing financial constraints and agency costs to minimize investment inefficiency in the Chinese market. J. Corp. Financ. 2016, 36, 111-130. [CrossRef] 
10. Castro, F.; Kalatzis, A.E.G.; Martins-Filho, C. Financing in an emerging economy: Does financial development or financial structure matter? Emerg. Mark. Rev. 2015, 23, 96-123. [CrossRef]

11. Mulier, K.; Schoors, K.; Merlevede, B. Investment-cash flow sensitivity and financial constraints: Evidence from unquoted European SMEs. J. Bank. Financ. 2016, 73, 182-197. [CrossRef]

12. Guariglia, A. Internal financial constraints, external financial constraints, and investment choice: Evidence from a panel of UK firms. J. Bank. Financ. 2008, 32, 1795-1809. [CrossRef]

13. Kaplan, S.N.; Zingales, L. Do investment-cash flow sensitivities provide useful measures of financing constraints? Q. J. Econ. 1997, 112, 169-213. [CrossRef]

14. Chen, F.; Hope, O.K.; Li, Q.; Wang, X. Financial reporting quality and investment efficiency of private firms in emerging markets. Account. Rev. 2011, 86, 1255-1288. [CrossRef]

15. Biddle, G.C.; Hilary, G.; Verdi, R.S. How does financial reporting quality relate to investment efficiency? J. Account. Econ. 2009, 48, 112-131. [CrossRef]

16. Gomariz, M.F.C.; Ballesta, J.P.S. Financial reporting quality, debt maturity and investment efficiency. J. Bank. Financ. 2014, 40, 494-506. [CrossRef]

17. Khan, M.K.; He, Y.; Kaleem, A.; Akram, U.; Hussain, Z. Remedial role of financial development in corporate investment amid financing constraints and agency costs. J. Bus. Econ. Manag. 2018, 19, 176-191. [CrossRef]

18. Cella, C. Institutional investors and corporate investment. Financ. Res. Lett. 2020, 32, 101169. [CrossRef]

19. Chung, C.Y.; Kim, H.; Ryu, D. Foreign investor trading and information asymmetry: Evidence from a leading emerging market. Appl. Econ. Lett. 2017, 24, 540-544. [CrossRef]

20. Tran, Q.T. Foreign ownership and investment efficiency: New evidence from an emerging market. Int. J. Emerg. Mark. 2020, 15, 1185-1199. [CrossRef]

21. Aggarwal, R.; Erel, I.; Ferreira, M.; Matos, P. Does governance travel around the world? Evidence from institutional investors \$. J. Financ. Econ. 2011, 100, 154-181. [CrossRef]

22. Brickley, J.A.; Lease, R.C.; Smith, C.W. Ownership structure and voting on antitakeover amendments. J. Financ. Econ. 1988, 20, 267-291. [CrossRef]

23. Almazan, A.; Hartzell, J.C.; Starks, L.T. Active institutional shareholders and costs of monitoring: Evidence from executive compensation. Financ. Manag. 2005, 34, 5-34. [CrossRef]

24. Ferreira, M.A.; Matos, P. The colors of investors' money: The role of institutional investors around the world. J. Financ. Econ. 2008, 88, 499-533. [CrossRef]

25. Lee, S.C.; Rhee, M.; Yoon, J. Foreign monitoring and audit quality: Evidence from Korea. Sustainability 2018, 10, 3151. [CrossRef]

26. Lee, J.; Kim, S.J.; Kwon, I. Corporate social responsibility as a strategic means to attract foreign investment: Evidence from Korea. Sustainability 2017, 9, 2121. [CrossRef]

27. Allen, F.; Carletti, E.; Marquez, R. Stakeholder governance, competition, and firm value. Rev. Financ. 2015, 19, 1315-1346. [CrossRef]

28. Bena, J.; Ferreira, M.A.; Matos, P.; Pires, P. Are foreign investors locusts? The long-term effects of foreign institutional ownership. J. Financ. Econ. 2017, 126, 122-146. [CrossRef]

29. UNCTAD. World Investment Report 2017: Investment and the Digital Economy; United Nations Publication: Geneva, Switzerland, 2017; ISBN 9789211129113.

30. Panda, B.; Leepsa, N.M. Agency theory: Review of theory and evidence on problems and perspectives. Indian J. Corp. Gov. 2017, 10, 74-95. [CrossRef]

31. Fama, E.F.; Jensen, M.C. Separation of Ownership and Control. J. Law Econ. 1983, 26, 301-325. [CrossRef]

32. Jensen, M.C. Agency costs of free cash flow, corporate finance, and takeovers. Am. Econ. Rev. 1986, 76, 323-329.

33. Stein, J.C. Efficient capital markets, inefficient firms: A model of myopic corporate behavior. Q. J. Econ. 1989, 104, 655-669. [CrossRef]

34. Malmendier, U.; Tate, G. CEO overconfidence and corporate investment. J. Financ. 2005, 60, 2661-2700. [CrossRef]

35. Koo, J.; Maeng, K. Foreign ownership and investment: Evidence from Korea. Appl. Econ. 2006, 38, 2405-2414. [CrossRef]

36. Liu, J. Fixed investment, liquidity, and access to capital markets: New evidence. Int. Rev. Financ. Anal. 2013, $29,189-201$. [CrossRef]

37. Sirsly, C.A.T.; Sur, S. Strategies for sustainability initiatives: Why ownership matters. Corp. Gov. 2013, 13, 541-550. [CrossRef]

38. Admati, A.R.; Pfleiderer, P. The "wall Street Walk" and shareholder activism: Exit as a form of voice. Rev. Financ. Stud. 2009, 22, 2645-2685. [CrossRef]

39. Huang, R.D.; Shiu, C.Y. Local effects of foreign ownership in an emerging financial market: Evidence from qualified foreign institutional investors in Taiwan. Financ. Manag. 2009, 38, 567-602. [CrossRef]

40. Bae, K.H.; Ozoguz, A.; Tan, H.; Wirjanto, T.S. Do foreigners facilitate information transmission in emerging markets? J. Financ. Econ. 2012, 105, 209-227. [CrossRef]

41. Kim, I.J.; Eppler-Kim, J.; Kim, W.S.; Byun, S.J. Foreign investors and corporate governance in Korea. Pacific Basin Financ. J. 2010, 18, 390-402. [CrossRef]

42. $\mathrm{Wu}, \mathrm{J} . ; \mathrm{Li}, \mathrm{S}$.; Selover, D.D. Foreign direct investment vs. foreign portfolio investment: The effect of the governance environment. Manag. Int. Rev. 2012, 52, 643-670. [CrossRef] 
43. Choi, S.; Hasan, I. Ownership, governance, and bank performance: Korean experience. Financ. Mark. Inst. Instrum. 2005, 14, 215-242. [CrossRef]

44. Park, H.Y.; Chae, S.J.; Cho, M.K. Controlling shareholders' ownership structure, foreign investors' monitoring, and investment efficiency. Invest. Manag. Financ. Innov. 2016, 13, 159-170. [CrossRef]

45. Peck-Ling, T.; Nai-Chiek, A.; Chee-Seong, L. Foreign ownership, foreign directors and the profitability of malaysian listed companies. Procedia Soc. Behav. Sci. 2016, 219, 580-588. [CrossRef]

46. Richardson, S. Over-investment of free cash flow. Rev. Account. Stud. 2006, 11, 159-189. [CrossRef]

47. Almeida, H.; Campello, M. Financial constraints, asset tangibility, and corporate investment. Rev. Financ. Stud. 2007, 20, 1429-1460. [CrossRef]

48. Rafailov, D. Financial slack and performance of bulgarian firms. J. Financ. Bank Manag. 2017, 5, 1-13. [CrossRef]

49. Chen, T.; Xie, L.; Zhang, Y. How does analysts' forecast quality relate to corporate investment efficiency? J. Corp. Financ. 2017, 43, 217-240. [CrossRef]

50. Labra, R.; Torrecillas, C. Estimating dynmic Panel data. A practical approach to perform long panels. Rev. Colomb. Estad. 2018, 41, 31-52. [CrossRef] 